\title{
Prevalence of asymptomatic bacteriuria among pregnant women in Nnewi, southeast Nigeria
}

\author{
A. O. IGWEGBE ${ }^{1 *}$, J. O. UGBOAJA ${ }^{1}$ and O.A. OKOLI ${ }^{2}$ \\ ${ }^{I}$ Department of Obstetrics and Gynaecology, Nnamdi Azikiwe University Teaching Hospital, \\ P.M.B. 5025. Nnewi, Nigeria. \\ ${ }^{2}$ Department of Microbiology Nnamdi Azikiwe University Teaching Hospital, \\ P.M.B. 5025. Nnewi, Nigeria. \\ *Corresponding author, E-mail: tigwegbe@yahoo.com
}

\begin{abstract}
Asymptomatic bacteriuria (ASB) in pregnancy is associated with obstetric complications including preeclampsia, pyelonephritis, preterm labour, low birth weight and prematurity. Determining the prevalence of asymptomatic bacteriuria among pregnant women locally is needed to justify routine screening for ASB in pregnancy. This cross sectional, case controlled study examined 440 women comprising equal numbers of pregnant and non pregnant women attending various clinics at Nnamdi Azikiwe University Teaching Hospital (NAUTH) Nnewi, Nigeria with the aim of determining the prevalence of ASB among them and the antibiotic sensitivity of the isolated organisms. Urine culture using MacConkay and blood agar were used to isolate bacteria organisms. Significant bacteriuria was defined as the finding of single pure isolate of $\geq 10^{5}$ in two consecutive, freshly voided, midstream urine. The prevalence of asymptomatic bacteriuria among the pregnant women was $19.5 \%(n=43)$ and $6.4 \%(n=14)$ for the non pregnant women. $\left(x^{2}=16.9,0 R=3.6, P=0.00\right)$. There was no significant influence of age $\left(\mathrm{x}^{2}=1.89, \mathrm{P}=0.39\right)$, parity $\left(\mathrm{x}^{2}=3.92, \mathrm{P}=0.14\right)$ or social class $\left(\mathrm{x}^{2}=5.7, \mathrm{p}=0.22\right)$ on the prevalence of asymptomatic bacteriuria in pregnancy. Escherichia coli (E. coli) was the commonest isolated organism, 30(52.6\%) followed by Staphylococcus aureus, 10 (17.5\%) and Klebsiella sp, 9 (15.8\%). The isolated E. coli was $100 \%$ sensitive to ofloxacin, nitrofurantoin and nalidixic acid and $83.3 \%, 73.3 \%$ and $66.7 \%$ sensitive to augmentin, gentamicin and cefuroxime, respectively. Sensitivity to ampicillin and cotrimoxazole were $43.3 \%$ and $30.0 \%$, respectively. The prevalence of asymptomatic bacteriuria among pregnant women attending antenatal clinic in NAUTH is high and the isolated organisms were mainly susceptible to ofloxacin, nitrofurantoin and nalidixic acid. Routine screening for ASB in pregnancy in the hospital is recommended for all pregnant women.
\end{abstract}

(C) 2012 International Formulae Group. All rights reserved.

Keywords: Prevalence, Asymptomatic bacteriuria, Nnewi, Nigeria.

\section{INTRODUCTION}

The changes that occur both in the structure and function of the urinary tract in pregnancy encourage upper urinary tract infections. These changes include dilatation of the renal calyces and the ureters and occur as early as the 14th week of pregnancy, thus implicating hormonal relaxation of the muscular layers of the renal tract (Cunningham et al., 2005). There is also 
further dilatation beginning at mid pregnancy because of the ureter compression by the enlarging gravid uterus. Increased vesicourethral reflux also increases this potential for multiplication of bacteria within the renal tract. As a result, urinary tract infections are the most common infections that complicate pregnancy.

True bacteriuria is defined as the presence of up to 100,000 colony forming units (CFUs) of a single pathogen per $\mathrm{ml}$ of two freshly voided mid-stream, clean catch urine specimens or a single catheterization specimen (Cunningham et al., 2005).

Asymptomatic bacteriuria (ASB) therefore, is the presence of true bacteriuria in an individual without symptoms of urinary tract infection. (Samuels and Colombo, 2002). The prevalence of ASB in pregnancy varies across the various regions of the world. In Nigeria the highest incidence of $86.6 \%$ was reported in Benin City, Niger Delta area (Akerele et al, 2001). In the southwestern part of the country, it ranges from $12.2 \%$ in AdoEkiti (Oyagade et al., 2004) to 21\% reported in Ibadan (Ifemeje et al., 2006; Akiloye et al., 2006). In Enugu, south-east Nigeria, Ezeome et al. (2006), reported an incidence of $15.1 \%$ The significance of ASB in pregnancy is that more than $50 \%$ of untreated cases progress to symptomatic urinary tract infections with adverse obstetric outcomes such as pyelonephritis, preterm labour, low birth weight, hypertensive disease, chorioamnionitis and prematurity (Ezeome et al., 2006; Ullah et al., 2006).

In view of these identified complications associated with ASB, many authors have proposed routine urine screening for ASB in all pregnant women at their first prenatal visit (Akerele et al., 2001; Oyagade et al., 2004; Ifemeje et al., 2006; Akiloye et al., 2006).

Prominent among these recommendations was the U.S. Preventive Services Task Force reaffirmation statement that strongly recommended routine screening for all pregnant women between $12^{\text {th }}-16^{\text {th }}$ of pregnancy (Calonge et al., 2008). This recommendation no doubt, carries with it some financial implications which may limit its applicability in resource constrained regions of the world like the sub-Saharan Africa. Therefore, in other to adjust local management protocols with respect to routine screening for asymptomatic bacteriuria in pregnant women, it is necessary to determine its prevalence within the locality.

This study therefore, aims at determining the prevalence of ASB among pregnant women in Nnewi as well as the influence of sociodemographic characteristics. The findings from this study will form the basis for making recommendations with respect to routine screening for ASB among pregnant women in our locality.

\section{MATERIALS AND METHODS}

\section{Study site}

The study was carried out in the Antenatal clinic, Family Planning clinic, Gynaecology and General Outpatient clinics and the Microbiology Department of Nnamdi Azikiwe University Teaching Hospital, Nnewi, Anambra State, which is a tertiary health institution in Nigeria with a catchment area of the five States of the South East geopolitical region. These states include Anambra, Enugu, Abia, Imo and Ebonyi States. It also receives referrals from some parts of Delta State of Nigeria.

\section{Study population}

The study population comprised consecutive pregnant women attending the antenatal clinic and an equal number of non pregnant women, who were attending the gynaecology, family planning and the general outpatient clinics of the hospital who met the inclusion criteria.

\section{Inclusion criteria}

- All pregnant women at gestational age $\leq$ 30 weeks;

- All women attending family planning, gynaecology and general outpatient clinics within the age of 15-49 years. 


\section{Exclusion criteria}

- All patients with history of urinary tract infection symptoms, diabetes mellitus, hypertension, renal diseases or sickle cell disease;

- Women with previously treated urinary tract infections;

- Women who are HIV positive;

- Women who are currently on antibiotics or had taken antibiotics during the course of the index pregnancy;

\section{Sample size}

The minimum sampling size was determined using the statistical formula of Fischer (Hassan, 1990) for calculating sample size.

$\mathrm{N}=\mathrm{Z}^{2} \mathrm{pq} / \mathrm{d}^{2}$ Where; $\mathrm{N}=$ Minimum sample size for a statistically significant survey

$\mathrm{Z}=$ Normal deviant at the portion of $95 \%$ Confidence interval $=1.96$

$\mathrm{p}=$ prevalence of bacteriuria in pregnancy in Enugu $=15.1 \%$ ( Ezeome IV, 2006);

$\mathrm{q}=1-\mathrm{p} ; \mathrm{d}=$ Margin of error acceptable or measure o precision $=0.05$

$\mathrm{N}=(1.96 \times 1.96) \times 0.15 \times 0.85$

$0.05 \mathrm{X} 0.05 ; \mathrm{N}=195.92=196$ pregnant women. We used a sample population of 220 pregnant women and 220 non pregnant women (a total of 440) to improve the power of the study.

\section{Data collection}

At the various clinics, women were first educated on the purpose and nature of the study as a group. Those who gave consent for the study were clinically evaluated for symptoms of urinary tract infections and the presence of the other exclusion criteria. The eligible women who met the inclusion criteria were recruited for the study and their sociodemographic data obtained through coded semi structured pre-tested questionnaires that were administered by the researchers.

The information obtained were age, gestational age, parity, level of education, occupation, religion and occupation of the husband. Attached to the questionnaire was a specimen proformal for documentation of the laboratory findings. Patients were assigned to social classes utilizing the method developed by Olusanya et al (1985) which considers the educational level of the woman and the occupation of the husband (Thirty women were not classified because they were single)

\section{Laboratory methods}

After completing the questionnaires, the eligible women were taught how to collect clean-catch midstream urine sample by thorough antero-posterior swabbing of the vulva with sterile water before urine collection. Thereafter, they were provided with two sterile universal containers. Two samples of 10-15 ml urine were obtained and immediately sent to the laboratory.

\section{Urine microscopy}

At the laboratory, $10 \mathrm{ml}$ of the urine sample was poured into a test tube and centrifuged for 5 minutes. The supernatant was discarded while a drop of the deposit was placed on a grease free slide and covered with a cover slip. It was then examined under the microscope at $40 \mathrm{X}$ magnification. The urine specimen was also examined for pus cells, bacteria, epithelial cells and red blood cells.

\section{Urine culture}

The urine samples were also immediately cultured on chocolate and MacConkey agar, and samples not cultured within two hours were stored at $4{ }^{\circ} \mathrm{C}$.

Using a sterile standard wire loop that delivers $0.002 \mathrm{ml}$ of urine, a loopful of urine sample was streaked evenly on dried plates of chocolate and MacConkey agar to obtain discrete colonies. The plates were incubated aerobically at $37{ }^{\circ} \mathrm{C}$ for 24 hours and were then counted for pure isolates. Identification of bacteria pathogens were made on the basis of Gram reaction, morphology and biochemical characteristics. Only colony counts yielding bacterial growth of $10^{5} \mathrm{cfu} / \mathrm{ml}$ or more of pure isolates from the two samples 
were deemed significant. Any urine specimen containing high colony counts with more than one species of bacteria was considered as being contaminated and hence, discarded.

\section{Testing for antimicrobial sensitivities of the} isolates

Using a sterile wire loop, small portion of the isolate on the plates were collected and streaked evenly onto a nutrient agar. Using a pair of sterile forceps, the sensitivity disc was placed on the surface. The plate was incubated at $37^{\circ} \mathrm{C}$ for 24 hours and the plates were read for zones of inhibition.

All the women who were positive for asymptomatic bacteriuria were referred to their attending physicians for treatment in accordance with the antibiotic sensitivity pattern.

\section{Data analysis}

Statistical analysis of the data collected was done with Epi-info statistical package, version 3.5.2 (2008). Continuous variables are expressed as means and standard deviations, while statistical relationships between variables were explored using chi square test and a p-value of $<0.05$ was considered statistically significant. Student's T-test was used to calculate the difference of means of the studied populations. The result is presented in tables.

\section{Ethical considerations}

Ethics approval for the study was obtained from the Nnamdi Azikiwe University Teaching Hospital Ethics Committee. Questionnaires were administered only to those patients who gave their consent, after due group counseling. Confidentiality was maintained at all stages of the research work and all the participating women had the right to withdraw from the study at any time after counseling. The research posed no hazards to the respondents.

\section{RESULTS}

The prevalence of asymptomatic bacteriuria among the pregnant women was $19.5 \%(n=43)$ and $6.4 \%(n=14)$ for the non pregnant women. This difference was statistically significant $\quad(\mathrm{x} 2=16.9, \quad 0 \mathrm{R}=3.6$, $\mathrm{P}<0.01)$.

The mean age of the women was 28.67 \pm 5.55 years while the mean parity was $2.01 \pm$ 1.61. Table 1 shows the sociodemographic profile of the respondents. Most of women were married $(91.1 \%, \mathrm{n}=401)$, had achieved at least secondary education $(93.4 \%, \mathrm{n}=411)$ and were traders $(38.2 \%, \mathrm{n}=168)$. The modal social class was class III $(40.2 \%, n=167)$. There was no significant difference ( $\mathrm{T}$ statistic $=1.97, \mathrm{p}=0.05)$ between the mean age of the pregnant women $(28.2 \pm 5.3$ years $)$ and that of the non-pregnant women (29.2 \pm .7 years)

Table 2 shows the prevalence rates of asymptomatic bacteriuria specific to various sociodemographic characteristics of the women. The prevalence was highest among women aged 30 years and above $(22.8 \%$, $\mathrm{n}=23)$ the grandmultiparae $(34.8 \%, \mathrm{n}=8)$, women with secondary education $(22.5 \%$, $\mathrm{n}=29)$, the widows $(25.0 \%, \mathrm{n}=1)$ and those who belong to social class IV $(28.3 \%, \mathrm{n}=15)$. However, there was no significant influence of age $\left(\mathrm{x}^{2}=1.89, \mathrm{P}=0.39\right)$, parity $\left(\mathrm{x}^{2}=3.92\right.$, $\mathrm{P}=0.14)$ or social class $\left(\mathrm{x}^{2}=5.7, \mathrm{p}=0.22\right)$.

Escherichia coli was the most common isolated organism, $30(52.6 \%)$ followed by Staphylococcus aureus, 10 (17.5\%) and Klebsiella sp., $9(15.8 \%)$. This is shown in Table 3.

Table 4 shows that the isolated E. coli was $100 \%$ sensitive to nitrofurantoin and nalidixic acid. It was $83.3 \%, 73.3 \%$ and $66.7 \%$ sensitive to amoxicillin-clavulanic acid combination, gentamicin and cefuroxime respectively. Its sensitivity to ampicillin and cotrimoxazole were $43.3 \%$ and $30.0 \%$ respectively. 
A. O. IGWEGBE et al. / Int. J. Biol. Chem. Sci. 6(1): 88-98, 2012

Table I: Distribution of Sociodemographic profile of the studied women.

\begin{tabular}{|c|c|c|c|c|c|c|}
\hline \multirow{2}{*}{$\begin{array}{l}\text { Socio-demographic } \\
\text { Characteristics }\end{array}$} & \multirow{2}{*}{$\begin{array}{c}\begin{array}{c}\text { Pregnant } \\
\text { women }\end{array} \\
\text { No }(\%)\end{array}$} & \multirow{2}{*}{$\begin{array}{c}\text { Non-pregnant women } \\
\text { No }(\%)\end{array}$} & \multicolumn{2}{|c|}{ Total } & \multirow[t]{2}{*}{ T-Statistic } & \multirow[t]{2}{*}{ P-value } \\
\hline & & & No & $\%$ & & \\
\hline \multicolumn{7}{|l|}{ Age } \\
\hline$<20$ & $7(3.2)$ & $5(2.3)$ & 12 & 2.7 & & \\
\hline $20-24$ & $46(20.9)$ & $47(21.4)$ & 93 & 21.1 & & \\
\hline $25-29$ & $66(30.0)$ & $56(25.5)$ & 122 & 27.7 & 1.97 & 0.05 \\
\hline $30-34$ & $65(29.5)$ & $68(30.9)$ & 133 & 30.2 & & \\
\hline $35-39$ & $35(15.9)$ & $39(17.7)$ & 74 & 16.9 & & \\
\hline$\geq 40$ & $1(0.5)$ & $5(2.3)$ & 6 & 1.4 & & \\
\hline \multicolumn{7}{|l|}{ Parity } \\
\hline $0-1$ & $107(48.6)$ & $74(33.6)$ & 181 & 41.1 & 2.48 & 0.01 \\
\hline $2-4$ & $90(40.9)$ & $130(59.1)$ & 220 & 50.0 & & \\
\hline$\geq 5$ & $23(10.5)$ & $16(7.3)$ & 39 & 8.9 & & \\
\hline \multicolumn{7}{|l|}{ Marital status } \\
\hline Married & 205(93.2) & $196(89.1)$ & 401 & 91.1 & & \\
\hline Single & $10(4.5)$ & $20(9.0)$ & 30 & 6.8 & & \\
\hline Widowed & $4(1.8)$ & $3(1.4)$ & 7 & 1.6 & & \\
\hline Separated/divorced & $1(0.5)$ & $1(0.5)$ & 2 & 0.5 & & \\
\hline \multicolumn{7}{|l|}{ Educational level } \\
\hline Tertiary & $77(35.0)$ & $73(33.2)$ & 150 & 34.1 & & \\
\hline Secondary & $129(58.9)$ & $132(60.0)$ & 261 & 59.3 & & \\
\hline Primary & $14(6.4)$ & $14(6.4)$ & 28 & 6.4 & & \\
\hline No formal education & $0(0.0)$ & $1(0.5)$ & 1 & 0.2 & & \\
\hline \multicolumn{7}{|l|}{ Social class } \\
\hline I & 21 & 22 & 43 & 10.5 & & \\
\hline
\end{tabular}


A. O. IGWEGBE et al. / Int. J. Biol. Chem. Sci. 6(1): 88-98, 2012

\begin{tabular}{lcccc} 
II & 63 & 47 & 110 & 26.8 \\
III & 77 & 90 & 167 & 40.7 \\
IV & 53 & 27 & 80 & 19.5 \\
V & 5 & 5 & 10 & 2.5 \\
Occupation & & & \\
Trader & $67(30.5)$ & $101(45.9)$ & 168 & 38.2 \\
Public servant & $67(30.5)$ & $61(27.7)$ & 128 & 29.1 \\
Student & $35(15.9)$ & $26(11.8)$ & 61 & 13.9 \\
Housewife & $37(16.8)$ & $20(9.1)$ & 57 & 13.0 \\
Artisan & $14(6.4)$ & $12(5.5)$ & 26 & 5.9 \\
Religion & & & \\
Catholic & $102(46.4)$ & $99(45.0)$ & 201 & 45.7 \\
Pentecostal & $59(26.8)$ & $66(30.0)$ & 125 & 28.4 \\
Anglican & $57(25.9)$ & $55(25.0)$ & 112 & 25.5 \\
Jehovah Witness & $1(0.4 \%)$ & $0(0.0)$ & 1 & 0.2 \\
Sabbath & $1(0.4 \%)$ & $0(0.0)$ & 1 & 0.2 \\
\hline
\end{tabular}


A. O. IGWEGBE et al. / Int. J. Biol. Chem. Sci. 6(1): 88-98, 2012

Table 2: Influence of socio demographic characteristics on the prevalence of ASB among the pregnant women.

\begin{tabular}{|c|c|c|c|c|c|}
\hline Characteristics & $\begin{array}{c}\text { Positive urine culture } \\
(\%)\end{array}$ & $\begin{array}{c}\text { Negative urine } \\
\text { culture }(\%)\end{array}$ & $\mathbf{X}^{2}$ & df & P-value \\
\hline \multicolumn{6}{|l|}{ Age } \\
\hline$<20$ & $2(28.6)$ & $5(71.4)$ & & & \\
\hline $20-30$ & $18(16.1)$ & $94(83.9)$ & 1.89 & 2 & 0.39 \\
\hline$\geq 30$ & $23(22.8)$ & $78(77.2)$ & & & \\
\hline \multicolumn{6}{|l|}{ Parity } \\
\hline $0-1$ & $18(16.8)$ & $89(83.2)$ & & & \\
\hline $2-4$ & $17(18.9)$ & $73(81.1)$ & 3.92 & 2 & 0.14 \\
\hline$\geq 5$ & $8(34.8)$ & $15(65.2)$ & & & \\
\hline \multicolumn{6}{|l|}{ Marital status } \\
\hline Married & $41(20.0)$ & $164(80.0)$ & & & \\
\hline Single & $1(10.0)$ & $9(90.0)$ & & & \\
\hline Widowed & $1(25.0)$ & $3(75.0)$ & 0.93 & 3 & 0.82 \\
\hline Separated/divorced & $0(0.0)$ & $1(100.0)$ & & & \\
\hline \multicolumn{6}{|c|}{ Highest educational level } \\
\hline Tertiary & $11(14.3)$ & $66(85.7)$ & & & \\
\hline Secondary & $29(22.5)$ & $100(77.5)$ & & & \\
\hline Primary & $3(21.4)$ & $11(78.6)$ & 2.09 & 3 & 0.35 \\
\hline \multicolumn{6}{|l|}{ Social class } \\
\hline I & $3(14.3)$ & $18(85.7)$ & & & \\
\hline II & $7(11.5)$ & $54(88.5)$ & 5.73 & 4 & 0.22 \\
\hline III & $17(22.1)$ & $60(77.9)$ & & & \\
\hline IV & $15(28.3)$ & $38(71.7)$ & & & \\
\hline V & $1(20.0)$ & $4(80.0)$ & & & \\
\hline
\end{tabular}


A. O. IGWEGBE et al. / Int. J. Biol. Chem. Sci. 6(1): 88-98, 2012

\section{Religion}

Catholic

Pentecosta

Anglican

Jehovah Witness

11(18.6)

$8(14.0)$

$0(0.0)$

$0(0.0)$

$78(76.5)$

48(81.4)

49(86.0)

1(100.0)

Sabbath

$1(100.0)$

Table 3: Bacterial isolates among pregnant women with significant bacteriuria.

\begin{tabular}{lll}
\hline Bacterial Isolates & $\begin{array}{l}\text { Number of women } \\
\text { with isolates }\end{array}$ & Percentage \\
\hline & & \\
Escherichia coli & 30 & 52.6 \\
Staphylococcus aureus & 10 & 17.5 \\
Klebsiella species & 9 & 15.8 \\
Other Coliforms & 5 & 8.8 \\
Other species & 3 & 5.3 \\
Total Isolates & $\mathbf{5 7}$ & $\mathbf{1 0 0 . 0}$ \\
\hline
\end{tabular}


Table 4: Distribution of the antibiotic sensitivity of the predominant organism (E.coli) isolated in women with ASB in pregnancy.

\begin{tabular}{lll}
\hline Antibiotics & $\begin{array}{l}\text { Number of sensitive isolates } \\
(\boldsymbol{E} \text {. coli })\end{array}$ & Percentage \\
\hline Ofloxacin & 30 & 100.0 \\
Nalidixic acid & 30 & 100.0 \\
Nitrofurantoin & 30 & 100.0 \\
Augmentin & 25 & 83.3 \\
Gentamicin & 22 & 73.3 \\
Cefuroxime & 20 & 67.7 \\
Ampicillin & 13 & 43.3 \\
Cotrimoxazole & 9 & 30.0 \\
\hline
\end{tabular}

\section{DISCUSSION}

Urinary tract infections, especially upper tract infections in pregnancy are associated with adverse maternal and perinatal effects. Asymptomatic bacteriuria is a significant risk factor for symptomatic urinary tract infections. Hence it has become a standard practice in developed countries to screen for, and treat all cases of ASB in pregnancy.

The prevalence of ASB in pregnancy varies widely among regions and even within the same country. This study found a high prevalence rate of $19.5 \%$ among the pregnant women which was comparable to $21.0 \%$ reported in Ibadan, Nigeria (Ifemeje et al., 2006; Akinloye et al., 2006). However, it is lower than $86.6 \%$ reported in Benin City, Nigeria (Akerele et al., 2001).

In Enugu, southeast Nigeria, Ezeome et al. (2006) reported a prevalence of $15.1 \%$ and this is lower than $19.5 \%$ found in this study. In Ethiopia and Ghana both in tropical Africa, rates of $9.8 \%$ (Tadesse, 2007) and 7.3\% (Turpin et al., 2007) had been reported respectively. The high prevalence rate of ASB in pregnancy found in this study indicates the need for routine screening for ASB among the antenatal mothers in our hospital.

As our antenatal women pay for their investigations from their pockets, it is possible therefore, that a policy of routine screening for ASB in pregnancy in our environment may suffer a setback on the basis of financial requirements for urine culture. This can be mitigated however, by exploring the use of simpler screening tests which have shown considerable efficacy in detecting bacteriuria such as the combination of nitrite test and the leucocyte esterase test (Kovavisarach et al., 2009). Although these tests may not be as sensitive and specific as urine culture, they can be used to select those pregnant women who would require further urine culture. In spite of the perceived high cost, it is considered beneficial to screen every pregnant woman at booking considering the high prevalence of ASB found in this study and its attendant obstetric and perinatal complications.

With respect to the influence of maternal age on ASB in pregnancy, this study did not establish any significant relationship of ASB in pregnancy with maternal age, although the rate was highest among those who were 30 years and above. This is similar to the report of Kovavisarach et al. (2009) in Thailand, Hazhir et al. (2007) in Iran and Akinloye (2006) in Nigeria. However, Omole - Ohonsi et al. (2008) in Kano, northern Nigeria and Tugrul et al. (2005) in Turkey reported increasing prevalence rate with increasing maternal age.

As regards the effect of parity, while increased prevalence of ASB in pregnancy was found among the multiparous women in 
Ibadan (Akinloye, 2006), no significant association was found in this study between ASB in pregnancy and parity. However, the rate was highest among the grandmultiparous women, indicating a closer surveillance for asymptomatic bacteriuria among this obstetric population.

Though most pregnant women with positive urine culture in this study belong to low socioeconomic status (class III \& IV), this was not statistically significant. This corroborates the report of Kovavisarach et al. (2009) in Thailand and Hazhir et al. (2007) in Iran. However, low socioeconomic status had been associated with an increased prevalence of ASB in pregnancy (Fatima and Ishrat, 2006).

It is implied from this study that routine screening for ASB in pregnancy should be recommended for all pregnant mothers irrespective of their parity and socioeconomic status in our environment.

Escherichia coli which is widely documented as the most common isolated organism in cases of ASB in pregnancy (Ullah et al., 2007; Hernández Blas et al., 2007; Abdullah and Al-Moslih, 2005) was similarly found in this study. The organism showed poor sensitivity to ampicillin and cotrimoxazole, the two commonly used antibiotics for treatment of urinary tract infections in pregnancy. This had also been noted in previous studies (Akinloye, 2006; Tadesse et al., 2007; Oyagade et al., 2004; Oyetunji et al., 2004; Aboderin et al., 2004). Therefore, treatment of ASB among the pregnant women should utilize the more effective antibiotics which, in this case include nitrofurantoin, amoxicillin-clavulanic acid combination, cefuroxime and gentamicin. All these antibiotics are safe in pregnancy. However, nitrofurantoin can cause haemolysis in G6PD deficient neonates and hence should be avoided in late trimester.

\section{Conclusion}

The prevalence of asymptomatic bacteriuria in pregnancy among women attending antenatal clinic in NAUTH Nnewi is high and significantly higher than that among the non pregnant women. There is no significant association between ASB in pregnancy and age, parity or social class. The predominant organism is E. coli with poor sensitivity to ampicillin and cotrimoxazole.

Routine screening for ASB in pregnancy in this hospital is thereby recommended for all pregnant women to prevent its adverse obstetric and perinatal outcome.

\section{ACKNOWLEDGEMENTS}

We are grateful to all nurses at the clinics from where the subjects were recruited, and staff of the Microbiology laboratory of Nnamdi Azikiwe University Teaching Hospital Nnewi for their assistance.

\section{REFERENCES}

Abdullah AA, Al-Moslih MI. 2005. Prevalence of asymptomatic bacteriuria in pregnant women in Sharjah, United Arab Emirates. East Mediterr Health J., 11(56): 1045-1052.

Aboderin AO, Ako-Nai AK, Zailani SB, Ajayi A, Adedosu AN. 2004. A study of asymptomatic bacteriuria in pregnancy in Ile-Ife, southwestern Nigeria. Afr. J. Clin. Exper. Microbio., 5(3): 252-259.

Akerele J, Abhulimen P, Okonofua F. 2001. Prevalence of asymptomatic bacteriuria among pregnant women in Benin City, Nigeria. J Obstet Gynaecol., 21(2): 141144.

Akinloye O, Ogbolu DO, Akinloye OM, Terry Alli OA. 2006. Asymptomatic bacteriuria of pregnancy in Ibadan, Nigeria: a reassessment. Br J Biomed Sci., 63(3): 109112.

Calonge N, Petitti DB, DeWitt TG, Dietrich A, Gregory KD, Harris R, Isham G, LeFevre ML, Leipzig R, LovelandCherry C, Marion LN, Melnyk B, Moyer VA, Ockene JK, Sawaya GF, Yawn BP. 2008. Screening for asymptomatic bacteriuria in adults: U.S. Preventive Services Task Force reaffirmation 
recommendation statement. Ann Intern Med., 149(1): 43-47.

Cunningham FG, Leveno KJ, Bloom SL, Hauth JC, Gilstrap111 LC, Wenstrom KD. 2005. Renal and Urinary Tract Disorders in Williams Obstetrics $\left(22^{\text {nd }}\right.$ edn). McGRAW-HILL Medical Publishing Division: USA.

Ezeome IV, Ikeme AC, Okezie OA, Onyebueke EA. 2006. Asymptomatic Bacteriuria (ASB) in Pregnant Women in Enugu, Nigeria. Trop J Obstet Gynaecol., 23(1): 12-13.

Fatima N, Ishrat S. 2006. Frequency and risk factors of asymptomatic bacteriuria during pregnancy. J Coll Physicians Surg Pak., 16(4): 273-275.

Hassan Titi. 1990. Inferential statistics. In Handbook of Research Methods in Medicine, Bankole MA (ed). Nigerian Educational Research and Development Council: Lagos; 167-212.

Hazhir S. 2007. Asymptomatic bacteriuria in pregnant women. Urol. J., 4(1): 24-27.

Hernández Blas F, López Carmona JM, Rodríguez Moctezuma JR, Peralta Pedrero ML, Rodríguez Gutiérrez RS, Ortiz Aguirre AR. 2007. Asymptomatic bacteruiria frequency in pregnant women and uropathogen in vitro antimicrobial sensitivity. Ginecol Obstet Mex., 75(6): 325-331.

Ifemeje AA, Adesina OA, Morhason- Bello IO, Mutiu WB, Kolade CO. 2006. Asymptomatic Bacteriuria amongst Pregnant Women at Ibadan. Trop. J. of Obst Gynaecol., 23(1): S8.

Kovavisarach E, Vichaipruck M, Kanjaraeutai S. 2009. Risk factors to asymptomatic bacteriuria in pregnant women. J. Med. Assoc. Thai., 92(5): 606-610.
Olusanya O, Okpere EE, Ezimokhai M. 1985. The importance of social class in voluntary fertility control in a developing country. West Afri J Med., 4: 205-212.

Omole-Ohonsi A, Nwokedi E. 2008. Asymptomatic bacteriuria in pregnancy in Kano, nothern Nigeria. Nigerian Hospital Practice, 2(4): 76-79.

Oyagade AO, Smith SI, Famurewa O .2004. Asymptomatic significant bacteriuria among pregnant women in Ado-Ekiti, Ekiti State, Nigeria. African Journal of Clinical and Experimental Microbiology, 5(1): 64-77.

Oyetunji JA, Ahmed Y, Nwobodo EI, Airede LR, Ekele BA. 2006. Asymptomatic bacteriuria in pregnancy in Sokoto, Nigeria. Sahel Medical Journal, 9(1): 1-6.

Samuels P, Colombo DF. 2002. Renal disease. In Obstetrics: Normal and Problem Pregnancies ( $4^{\text {th }}$ edn), Gabbe SG, Niebyl JR, Simpson JL (eds). Churchill Livingstone : USA; 1067-1068.

Tadesse A, Negash M, Ketema LS .2007. Asymtomatic bacteriuria in pregnancy: assesment of prevlence, microbial agents and their antimicrobial sensitivty pattern in Gondar Teaching Hospital, northwest Ethiopia. Ethiop Med J., 45(2): 143-149.

Turpin CA, Minkah B, Danso KA, Frimpong EH. 2007. Asymptomatic bacteriuria in pregnant women attending antenatal clinic at Komfo Anokye Teaching Hospital, Kumasi, Ghana. Ghana Med J., 41(1): 26-29.

Ullah MA, Barman A, Siddique MA, Haque AK. 2007. Prevalence of asymptomatic bacteriuria and its consequences in pregnancy in a rural community of Bangladesh. Bangladesh Med. Res. Counc. Bull., 33(2): 60-64. 